\title{
PENDIDIKAN/PEKERJAAN MATERNAL DAN FAKTOR RISIKO PREEKLAMPSIA: STUDI EPIDEMIOLOGI DI KOTA TERNATE
}

\author{
Lilie Fransiska ${ }^{1}$, Edi Patmini², Abdul Wahab³, Ova Emilia ${ }^{4}$
}

\begin{abstract}
Background: Preeclampsia is one of leading cause of maternals and infants morbidity and mortality that can be prevented by an early detection in pregnant woman who have risk factors to preeclampsia. Early detection and management have a significant role in decreasing maternal and infant mortality rate.

Objective: To determine the proportion of pregnancy with risk to preeclampsia and related risk factors.

Method: This research is an observational study with cross sectional design. The independent variables are level of maternal education, and occupation. The dependent variable is increased risk of preeclampsia during pregnancy. Data collected by direct interview, physical examination and laboratory examination. Data analysis was done with SPSS programme.

Results and Discussion: The result showed that there was no significant difference in maternal educational level with the risk of preeclampsia $(p=0,919)$, and there is no significant difference between maternal working status with risk of preeclampsia $(p=0,435)$.

Conclusions: This research showed that maternal level of education and working status didn't have a significant influence to the risk of preeclampsia $(p>0,05)$.
\end{abstract}

Keywords : maternal occupation, level of maternal education, risk of preeclampsia

\section{ABSTRAK}

Latar Belakang: Preeklampsia merupakan salah satu penyebab morbiditas dan mortalitas pada ibu dan bayi yang dapat dicegah dengan melakukan deteksi dini pada ibu hamil yang memiliki risiko terhadap terjadinya preeklampsia. Tujuan: Penelitian ini bertujuan untuk menentukan proporsi ibu hamil dengan risiko preeklampsia di Kota Ternate dan faktor-faktor risiko yang terkait. Hasil penelitian ini diharapkan supaya dapat digunakan untuk meningkatkan kesehatan ibu dan anak di Kota Ternate.

Metode: Penelitian ini merupakan penelitian observasional dengan menggunakan desain studi potong lintang. Variabel bebas adalah tingkat pendidikan dan jenis pekerjaan ibu. Variabel terikat adalah peningkatan risiko terjadinya preeklampsia selama kehamilan. Data dikumpulkan dengan melakukan wawancara langsung, pemeriksaan fisik, dan pemeriksaan laboratorium. Selanjutnya analisis deskriptif pada data penelitian dilakukan dengan menggunakan program SPSS.

Hasil dan Pembahasan: Hasil analisis menunjukkan bahwa tidak ada perbedaan bermakna antara kelompok berpendidikan tinggi dan kelompok berpendidikan rendah $(p=0,919)$, serta antara kelompok bekerja dan tidak bekerja $(p=0,435)$.

Kesimpulan: Faktor pendidikan dan pekerjaan maternal tidak memiliki pengaruh yang bermakna terhadap risiko terjadinya preeklampsia $(p>0,05)$.

Kata kunci : pekerjaan ibu, pendidikan ibu, risiko preeklampsia

\footnotetext{
Mahasiswa S1 Fakultas Kedokteran UGM, Yogyakarta

Bagian Obstetri dan Ginekologi Fakultas Kedokteran UGM

Bagian IImu Kesehatan Masyarakat UGM, Yogyakarta

4 Bagian Obstetri dan Ginekologi Fakultas Kedokteran UGM
} 


\section{PENDAHULUAN}

Angka kematian ibu dan anak merupakan indikator yang paling peka untuk menilai keberhasilan program kesehatan ibu dan anak. ${ }^{1}$ Diperkirakan terdapat 500.000 kematian ibu di seluruh dunia setiap tahunnya. ${ }^{2}$ Tingginya angka kematian ibu dan anak cenderung menggambarkan taraf kesehatan ibu dan anak yang masih buruk. Menurut SDKI 2012, angka kematian ibu di Indonesia berada pada angka 359 kematian ibu per 100.000 kelahiran hidup. ${ }^{3}$ Angka tersebut menyebabkan Indonesia memiliki angka kematian maternal paling tinggi di Asia Tenggara.

Penelitian menunjukkan bahwa preeklampsia/ eklampsia merupakan salah satu penyebab paling banyak kematian maternal di Indonesia. ${ }^{1}$ Berdasarkan Laporan Rutin Program Kesehatan Ibu Dinas Kesehatan Provinsi tahun 2012, hipertensi dalam kehamilan (25\%) merupakan penyebab kematian ibu di Indonesia yang paling tinggi setelah pendarahan (30\%) dan kemudian diikuti oleh infeksi (5\%), partus lama (5\%), dan abortus (1\%). ${ }^{3}$ Preeklampsia merupakan sindrom yang spesifik terhadap kehamilan yang dapat mempengaruhi semua sistem organ. Hipertensi dengan proteinuria yang signifikan yang timbul setelah usia 20 minggu merupakan kriteria untuk menentukan diagnosis preeklampsia. Eklampsia adalah onset kejang yang terjadi pada wanita hamil dengan preeklampsia, yang dapat muncul sebelum, selama, atau setelah proses persalinan. Kedua faktor yang menyebabkan peningkatan angka kematian ibu dan bayi sebenarnya dapat dicegah dengan adanya deteksi dini. ${ }^{4}$ Selain itu, faktor lain penyebab tingginya angka mortalitas ibu dan anak di Indonesia adalah gagalnya pemerintah dalam mengendalikan laju pertumbuhan penduduk. ${ }^{5}$

Di negara maju, surveillans telah dilakukan dengan baik sehingga dapat diberikan intervensi dini bagi ibu penderita preeklampsia yaitu melalui proses terminasi kehamilan di saat usia bayi sudah dapat dilahirkan. ${ }^{6} \mathrm{Hal}$ tersebut sangat menurunkan angka kematian ibu pada saat melahirkan yang dikarenakan oleh preeklampsia. Di negara berkembang, proses surveillans ini masih tidak berjalan dengan baik. Sembilan puluh sembilan persen kematian terkait kehamilan terjadi di negara berpenghasilan menengah dan rendah. Wanita yang terlahir di negara berkembang memiliki risiko untuk mengalami preeklampsia 7 kali lebih besar dan 3 kali lebih besar untuk menjadi eklampsia. Salah satu penyebabnya adalah dikarenakan $15-30 \%$ wanita yang menjalani pemeriksaan prenatal tidak diperiksa tekanan darahnya. $^{7}$

Di Indonesia sendiri kegiatan surveillans belum dilakukan secara merata. Tingkat kesehatan ibu dan anak juga cenderung bervariasi antar daerah di Indonesia. Angka kematian bayi di Indonesia adalah sebesar 34 kematian bayi per 1000 kelahiran hidup, sedangkan di Provinsi Maluku Utara, angka kematian bayi masih berada pada angka 62 kematian bayi per 1000 kelahiran hidup. ${ }^{8}$ Menurut SDKI tahun 2012, terdapat lonjakan signifikan pada angka kematian ibu di Indonesia. Angka kematian ibu menurut survei tersebut berada pada angka 359 kematian per 100.000 kelahiran hidup, sedangkan di Provinsi Maluku Utara, angka kematian ibu berada pada angka 387 kematian per 100.000 kelahiran hidup. ${ }^{9}$

Berdasarkan permasalahan di atas, maka penulis terdorong untuk melakukan penelitian yang berkaitan dengan deteksi dini risiko tinggi pada ibu hamil khususnya ibu hamil dengan preeklampsia di Kota Ternate. Dengan penelitian ini, diharapkan dapat mengetahui proporsi ibu-ibu hamil dengan risiko preeklampsia yang memiliki risiko tinggi terhadap terjadinya morbiditas maupun mortalitas pada bayi dan ibu. Dengan diketahuinya proporsi tersebut, kami berharap dapat melakukan upaya antisipasi dengan melibatkan keluarga, masyarakat, pemerintah daerah, serta tenaga kesehatan setempat sehingga dapat menurunkan angka morbiditas dan mortalitas ibu dan bayi. 


\section{METODE}

Penelitian ini merupakan penelitian observasional dengan rancangan studi potong lintang yang dilaksanakan di Kota Ternate. Penelitian ini dilakukan pada tanggal 23 hingga 30 Agustus 2013. Populasi sasaran dalam penelitian ini adalah ibu-ibu hamil yang tinggal di Kota Ternate. Adapun populasi terjangkaunya adalah ibu-ibu hamil yang diundang oleh bidan Puskesmas dan memenuhi undangan tersebut.

Penentuan besar sampel dalam penelitian ini menggunakan parameter proporsi ibu hamil risti, yaitu $30 \%$ dengan alfa 0,05 ( $\mathrm{Cl}=95 \%$ ) dan power $90 \%$. Dengan mempertimbangkan variasi wilayah dan jumlah populasi di masing-masing Puskesmas maka dipertimbangkan design effect sebesar 2 sehingga dibutuhkan jumlah sampel sebanyak 162 subyek.

Puskesmas yang dipilih untuk mengikuti penelitian berjumlah sebanyak 6 Puskesmas, yaitu Puskesmas Siko, Puskesmas Sulamadaha, Puskesmas Kota, Puskesmas Gambesi, Puskesmas Kalumpang, dan Puskesmas Kalumata. Subyek penelitian yang menyetujui untuk diikutsertakan dalam penelitian mengisi lembar informed consent terlebih dahulu.

Subyek penelitian diwawancarai oleh bidan Puskesmas dengan menggunakan panduan kuesioner dan diundang kembali untuk pemeriksaan laboratorium oleh peneliti di Puskesmas. Pemeriksaan laboratorium meliputi pemeriksaan kadar hemoglobin yang menggunakan strip test (EasyTouch $^{\circledR}$ ) dan pemeriksaan urin (kadar glukosa, protein dan leukosit) yang menggunakan strip test (Arkray).

Subyek penelitian dikelompokkan menjadi kelompok yang memiliki dan tidak memiliki risiko preeklampsia. Subyek penelitian dikatakan memiliki risiko untuk mengalami preeklampsia jika memiliki lebih dari satu faktor risiko nomor 1 sampai 7 atau salah satu factor nomor 8 sampai 11 berikut ini ${ }^{10}$ :

1. nullipara

2. berusia $\geq 40$ tahun

3. $\mathrm{BMI} \geq 35 \mathrm{~kg} / \mathrm{m}^{2}$ pada kunjungan pertama
4. interval kehamilan $\geq 10$ tahun

5. kehamilan kembar

6. riwayat hipertensi pada kehamilan sebelumnya

7. riwayat preeklampsia pada keluarga (khususnya ibu atau saudara perempuan)

8. penyakit ginjal kronik

9. penyakit autoimun seperti sistemik lupus eritematosus atau sindrom anti fosfolipid

10. diabetes tipe 1 atau 2

11. hipertensi kronik

Setelah dikelompokkan berdasarkan risiko terjadinya preeklampsia, dilakukan analisis data dengan menggunakan SPSS untuk melihat hubungan tingkat pendidikan, dan jenis pekerjaan terhadap adanya risiko terjadinya preeklampsia. Tingkat pendidikan didefinisikan sebagai sekolah atau jenjang pendidikan formal terakhir yang ditamatkan oleh subyek penelitian. Subyek penelitian dikelompokkan berdasarkan tingkat pendidikan menjadi berpendidikan rendah (pendidikan $\leq$ SMP) dan berpendidikan tinggi ( $\geq \mathrm{SMA}$ ). Jenis pekerjaan didefinisikan sebagai kegiatan keseharian yang dilakukan oleh subyek penelitian untuk memperoleh penghasilan. Subyek penelitian dikelompokkan berdasarkan jenis pekerjaan menjadi bekerja dan tidak bekerja.

\section{HASIL DAN PEMBAHASAN}

Pada penelitian didapatkan jumlah subyek penelitian sebanyak 227 orang. Persebaran subyek penelitian pada 6 Puskesmas terpilih dapat dilihat pada Tabel 1 . Sebanyak 43,2\% subyek penelitian memiliki risiko untuk mengalami preeklampsia. Karakteristik subyek penelitian dapat dilihat pada Tabel 2. Beberapa riwayat penyakit dahulu yang dimiliki oleh subyek penelitian adalah hipertensi pada kehamilan sebelumnya (1,8\%), riwayat preeklampsia pada keluarga (1,3\%), penyakit ginjal kronik $(0,4 \%)$, diabetes mellitus $(1,3 \%)$, dan hipertensi kronik $(1,3 \%)$. 
Tabel 1. Distribusi responden berdasarkan Puskesmas dan umur kehamilan

\begin{tabular}{llccc}
\hline \multirow{2}{*}{ No. } & Puskesmas & \multicolumn{2}{c}{ Umur Kehamilan } & \multirow{2}{*}{ Total } \\
\cline { 3 - 4 } & & $\leq 28$ minggu & $>28$ minggu & \\
\hline 1 & Sulamadaha & 35 & 5 & 40 \\
2 & Siko & 5 & 32 & 37 \\
3 & Kalumpang & 25 & 8 & 33 \\
4 & Kota & 34 & 18 & 52 \\
5 & Kalumata & 16 & 18 & 34 \\
6 & Gambesi & 19 & 12 & 31 \\
\hline & Total & 134 & 93 & 227 \\
\hline
\end{tabular}

Tabel 2. Gambaran demografis responden

\begin{tabular}{|c|c|c|}
\hline Variabel & Jumlah (n) & Persentase (\%) \\
\hline \multicolumn{3}{|l|}{ Paritas } \\
\hline Nullipara & 77 & 33,9 \\
\hline Multipara & 149 & 65,6 \\
\hline Missing & 1 & 0,4 \\
\hline \multicolumn{3}{|l|}{ Usia maternal } \\
\hline$\leq 20$ tahun & 28 & 12,3 \\
\hline $21-30$ tahun & 125 & 55,1 \\
\hline $31-40$ tahun & 70 & 30,8 \\
\hline$>40$ tahun & 4 & 1,8 \\
\hline \multicolumn{3}{|l|}{ BMI sebelum hamil } \\
\hline$\leq 35 \mathrm{~kg} / \mathrm{m}^{2}$ & 85 & 37,4 \\
\hline$>35 \mathrm{~kg} / \mathrm{m}^{2}$ & 2 & 0,9 \\
\hline Missing & 140 & 61,7 \\
\hline \multicolumn{3}{|l|}{ BMI setelah hamil } \\
\hline$\leq 35 \mathrm{~kg} / \mathrm{m}^{2}$ & 216 & 95,2 \\
\hline$>35 \mathrm{~kg} / \mathrm{m}^{2}$ & 6 & 2,6 \\
\hline Missing & 5 & 2,2 \\
\hline \multicolumn{3}{|l|}{ Interval kehamilan } \\
\hline$>10$ tahun & 2 & 0,9 \\
\hline$\leq 10$ tahun & 225 & 99,1 \\
\hline \multicolumn{3}{|l|}{ Jumlah janin } \\
\hline Kembar & 3 & 1,3 \\
\hline Tunggal & 200 & 88,1 \\
\hline Missing & 24 & 10,6 \\
\hline \multicolumn{3}{|l|}{ Kebiasaan merokok } \\
\hline Ya & 8 & 3,5 \\
\hline Tidak & 217 & 95,6 \\
\hline Missing & 2 & 0,9 \\
\hline \multicolumn{3}{|l|}{ Tingkat pendidikan } \\
\hline$\leq \mathrm{SMP}$ & 61 & 26,9 \\
\hline$\geq \mathrm{SMA}$ & 166 & 73,1 \\
\hline \multicolumn{3}{|l|}{ Pekerjaan ibu } \\
\hline Bekerja & 50 & 22,0 \\
\hline Tidak bekerja & 177 & 78,0 \\
\hline
\end{tabular}


Berdasarkan hasil analisis data yang ditunjukkan pada Tabel 3, terlihat bahwa tidak terdapat perbedaan bermakna antara kelompok subyek berpendidikan tinggi dan berpendidikan rendah terhadap risiko terjadinya preeklampsia $(p=0,919)$.

Tabel 3. Hubungan risiko preeklampsia terkait tingkat pendidikan ibu

\begin{tabular}{lccccc}
\hline Variabel & $\begin{array}{c}\text { Risiko } \\
\text { preeklampsia }\end{array}$ & $\begin{array}{c}\text { Tidak berisiko } \\
\text { preeklampsia }\end{array}$ & OR* & $95 \% \mathrm{Cl}$ & $p_{\text {-value }}$ \\
\hline Tingkat & & & & & \\
$\begin{array}{c}\text { pendidikan ibu } \\
\text { S SMP }\end{array}$ & 26 & 35 & 1,031 & $0,570-$ & 0,919 \\
$\geq$ SMA & 72 & 94 & & 1,866 & \\
\hline
\end{tabular}

*Odds Ratio

Pekerjaan dari subyek penelitian berkisar dari pegawai negeri sipil, pegawai swasta, buruh dan lainnya. Berdasarkan analisis data yang ditunjukkan pada Tabel 4, terlihat bahwa tidak terdapat perbedaan bermakna antara kelompok subyek yang bekerja dan tidak bekerja terhadap risiko terjadinya preeklampsia $(p=0,435)$.

Tabel 4. Hubungan risiko preeklampsia terkait pekerjaan ibu

\begin{tabular}{lccccc}
\hline Variabel & $\begin{array}{c}\text { Risiko } \\
\text { preeklampsia }\end{array}$ & $\begin{array}{c}\text { Tidak berisiko } \\
\text { preeklampsia }\end{array}$ & $\mathrm{OR}^{*}$ & $95 \% \mathrm{Cl}$ & $\rho$-value \\
\hline $\begin{array}{c}\text { Pekerjaan ibu } \\
\text { Bekerja }\end{array}$ & & & & & \\
Tidak & 24 & 26 & 1,285 & $0,684-$ & 0,435 \\
bekerja & 74 & 103 & & 2,413 & \\
\hline
\end{tabular}

* Odds Ratio

Penelitian ini menunjukkan bahwa tidak ada hubungan antara tingkat pendidikan dan jenis pekerjaan, terhadap risiko terjadinya preeklampsia. Hasil penelitian ini berbeda dengan hasil penelitian sebelumnya.

Tingkat pendidikan menggambarkan secara tidak langsung tingkat sosioekonomi subyek tersebut. Seseorang dengan tingkat pendidikan yang tinggi diharapkan memiliki kesadaran mengenai pola hidup yang sehat yang lebih baik. ${ }^{11}$ Kelompok subyek dengan tingkat pendidikan yang lebih tinggi diduga akan memiliki informasi lebih banyak mengenai preeklampsia, faktor risiko yang terkait dan cara pencegahannya. ${ }^{12}$ Tingkat pendidikan yang tinggi juga akan menjadikan status sosial dan ekonomi seseorang menjadi lebih baik. ${ }^{13}$ Studi yang dilakukan oleh Tsigas (2006), menunjukkan bahwa tingkat pendidikan dapat mempengaruhi perilaku dalam mencari informasi mengenai preeklampsia sehingga dapat berpengaruh secara tidak langsung pada risiko terjadinya preeklampsia.

Hasil penelitian yang berbeda ini dapat disebabkan oleh karena subyek penelitian yang berbeda, pengambilan data yang dilaksanakan 
sebanyak satu kali, dan perbedaan standar pendidikan yang digunakan. Selain itu, tingkat pengetahuan masyarakat tidak hanya dipengaruhi oleh tingkat pendidikan formal yang telah diselesaikan tetapi juga oleh faktor sosiokultural yang berada di dalam masyarakat tersebut.

Studi menunjukkan bahwa aktivitas tubuh yang berat akan meningkatkan risiko terjadinya preeklampsia jika dibandingkan dengan ibu hamil yang tidak beraktivitas berat (adj. OR=1,65; 95\% $\mathrm{Cl}=1,11$, 2,43 ) dan tidak terdapat peningkatan risiko preeklampsia yang bermakna pada wanita dengan tingkat aktivitas fisik yang sedang. ${ }^{14}$

Hasil penelitian ini menunjukkan bahwa tidak ada perbedaan bermakna antara subyek yang bekerja dan subyek yang tidak bekerja terhadap risiko terjadinya preeklampsia. Hasil penelitian yang sedikit berbeda ini dapat disebabkan oleh jenis pekerjaan subyek yang belum dikelompokkan berdasarkan lama dan beratnya bekerja. Penelitian lebih lanjut diharapkan dapat mengelompokkan subyek penelitian berdasarkan berat dan lamanya subyek bekerja. Selain itu, faktor stress pada subyek juga merupakan sesuatu yang dapat mempengaruhi hasil dari penelitian.

\section{KESIMPULAN DAN SARAN}

Proporsi subyek penelitian di Kota Ternate yang berisiko mengalami preeklampsia adalah sebesar $43,2 \%$. Tidak ada hubungan yang bermakna antara tingkat pendidikan dan pekerjaan ibu terhadap risiko terjadinya preeklampsia.

\section{DAFTAR PUSTAKA}

1. Yuliawati S. Analisis Faktor-Faktor Risiko yang Mempengaruhi Terjadinya Preeklampsia di Rumah Sakit Pandan Arang Boyolali. Universitas Gadjah Mada; 2001.

2. Prata N, Passano P, Sreenivas A, Gerdts CE. Maternal Mortality in Developing Countries/ : Challenges in Scaling-up Priority Interventions. 2010;6:31127.

3. Kementrian Kesehatan RI. Profil Kesehatan Indonesia 2012. 2013.

4. Mogren I, Hogberg U, Winkvist A, Stenlund H. Familial Occurrence of Preeclampsia. Sweden: the National Institute of Public Health and the Medical Faculty, Umea University; 1999.

5. Mackenzie C. International Federation of Gynecology and Obstetrics [Internet]. 2013 [cited 2014 Apr 11]. Available from: http://www.figo.org/ news/maternal-mortality-rate-rises-indonesia0011597

6. Roberts JM, Gammill HS. Preeclampsia: recent insights. Hypertension [Internet]. 2005 Dec [cited 2014 Jun 12];46(6):1243-9. Available from: http:/ /www.ncbi.nlm.nih.gov/pubmed/16230510

7. Bender RM, Ryan BAGL. Pre-eclampsia and eclampsia/ : global challenges in low resource settings complete with proposed interventions in rural Haiti. 2013;3(1):1-6.

8. Kementrian Kesehatan RI. Data dan Informasi Kesehatan Provinsi maluku Utara. 2013.

9. Saputra W. Arah dan Strategi Kebijakan Penurunan Angka Kematian Ibu (AKI), Angka Kematian Bayi (AKB) dan Angka Kematian Balita (AKABA) di Indonesia. 2013.

10. NICE. Hypertension in Pregnancy [Internet]. 2013 [cited 2014 Jun 29]. Available from: http:// publications.nice.org.uk/hypertension-inpregnancy-qs35/quality-statement-2-antenatalassessment-of-pre-eclampsia-risk

11. Brunello G, Fort M, Schneeweis N, Winter-Ebmer R. The Causal Effect of Education on Health: What is the Role of Health Behaviors? Discuss Pap Ser. 2011;

12. Djannah SN, Arianti IS.Gambaran Epidemiologi Kejadian Preeklampsia / Eklampsia Di RSU PKU Muhammadiyah Yogyakarta Tahun 2007 - 2009. 2009;(0274).

13. Higgins $C$, Lavin T, Metcalfe O. Health Impacts of Education: a review. Ireland: Institute of Public Health; 2008.

14. Klemmensen K, Knudsen VK, Juhl M, Halldorsson TI. Does Leisure Time Physical Activity in Early Pregnancy Protect Against Pre-eclampsia/ ? Prospective Cohort in Danish Women. 2008;98107. 


\section{LAMPIRAN}

\section{KUESIONER 1: FORM ANAMNESIS}

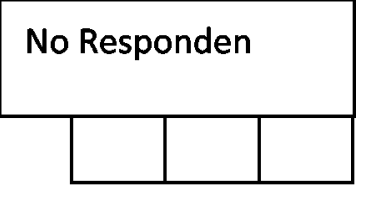

IDENTITAS:

\begin{tabular}{ll}
\hline Nama & Alamat dan kontak \\
Usia ibu & : \\
Pendidikan Ibu & : \\
Pekerjaan Ibu & Usia Suami \\
Pendidikan suami & :
\end{tabular}

Kebiasaan/Pola hidup

\begin{tabular}{|l|l|}
\hline Kebiasaan merokok & 1. Ya 2. Tidak \\
$\begin{array}{l}\text { Bila ya, berapa batang rokok dihabiskan } \\
\text { dalam } 24 \text { jama........................ }\end{array}$ &
\end{tabular}

\section{RIWAYAT OBSTETRI}

Paritas $\quad$ : G....P... A...

\begin{tabular}{|c|c|c|c|c|c|c|c|c|c|c|c|}
\hline \multirow[b]{2}{*}{$\begin{array}{c}\text { Anak } \\
\text { ke }\end{array}$} & \multirow[b]{2}{*}{ Tahun } & \multicolumn{3}{|c|}{ Keadaan Bayi } & \multirow[b]{2}{*}{$\begin{array}{c}\text { Usia } \\
\text { kehamilan }\end{array}$} & \multirow[b]{2}{*}{$\mathrm{BBL}$} & \multicolumn{3}{|c|}{ Proses Kelahiran } & \multirow{2}{*}{$\begin{array}{c}\text { Kondisi anak } \\
\text { (sehat/sakit/ } \\
\text { meninggal) }\end{array}$} & \multirow[b]{2}{*}{ Penolong } \\
\hline & & $A b$ & LH & $\begin{array}{c}\mathrm{L} \\
\mathrm{M}\end{array}$ & & & Spontan & $\begin{array}{c}\text { Persalinan } \\
\text { dengan } \\
\text { alat }\end{array}$ & SC & & \\
\hline & & & & & & & & & & & \\
\hline & & & & & & & & & & & \\
\hline & & & & & & & & & & & \\
\hline & & & & & & & & & & & \\
\hline & & & & & & & & & & & \\
\hline
\end{tabular}




\begin{tabular}{|c|l|c|c|}
\hline No & \multicolumn{1}{|c|}{ Pertanyaan } & Ya & Tidak \\
\hline \multicolumn{2}{|c|}{ Riwayat kehamilan sebelumnya } & & \\
\hline & Jika merupakan anak pertama langsung menuju ke pertanyaan nomor 3. & & \\
\hline 1. & $\begin{array}{l}\text { Jika ini bukan merupakan kehamilan pertama, apakah pada kehamilan } \\
\text { sebelumnya dengan hipertensi? }\end{array}$ & & \\
\hline & Jika ya, apakah kehamilan tersebut harus diakhiri sebelum waktunya? & & \\
\hline & Jika ya, pada kehamilan berapa kehamilan tersebut harus diakhiri? & $\ldots \ldots \ldots . . . \mathrm{mg}$ \\
\hline
\end{tabular}

\begin{tabular}{|c|c|c|}
\hline \multicolumn{3}{|c|}{ Riwayat Kehamilan Sekarang } \\
\hline 1. & Apakah dalam kehamilan sekarang terdapat riwayat perdarahan vaginal? & \\
\hline & Jika ya pada usia kehamilan berapa? & ..............mg \\
\hline & \multicolumn{2}{|l|}{ Apakah perdarahan tersebut sudah berhenti? } \\
\hline & \multicolumn{2}{|l|}{ Jika ya pada usia kehamilan berapa perdarahan tersebut berhenti } \\
\hline & $\begin{array}{l}\text { Bagaimana jumlah perdarahannya? (sebutkan perdarahan yang paling banyak } \\
\text { selama kehamilan) }\end{array}$ & $\begin{array}{l}\text { Flek/seperti } \\
\text { menstruasi hari ke } \\
\text { 1atau 2/banyak } \\
\text { melebihi mentruasi }\end{array}$ \\
\hline \multirow[t]{3}{*}{2.} & Apakah anda menderita penyakit diabetes (kencing manis)? & \\
\hline & Jika ya, apakah anda menggunakan obat-obatan untuk mengontrol gula darah? & \\
\hline & Jika ya, sebutkan nama obatnya & \\
\hline 3. & Pernahkah dalam kehamilan ini ada darah di urin Anda? & \\
\hline 4. & $\begin{array}{l}\text { Pernahkah dalam kehamilan ini ada pasir, kerikil, atau batu yang ikut keluar } \\
\text { bersama urin Anda saat Anda berkemih? }\end{array}$ & \\
\hline 5. & $\begin{array}{l}\text { Apakah dalam kehamilan ini Anda pernah menderita penyakit infeksi kandung } \\
\text { kemih atau ginjal? }\end{array}$ & \\
\hline \multirow[t]{5}{*}{6.} & Apakah anda mempunyai penyakit hipertensi? & \\
\hline & Jika Ya, sejak kapan & $\begin{array}{l}\text { Usia kehamilan.... mg/ } \\
\text { sebelum kehamilan }\end{array}$ \\
\hline & \multicolumn{2}{|l|}{ Berapa tekanan darah yang paling tinggi? } \\
\hline & \multicolumn{2}{|l|}{$\begin{array}{l}\text { Apakah anda mengkonsumsi o bat tekanan darah tinggi untuk menurunkan } \\
\text { kehamilan? }\end{array}$} \\
\hline & \multicolumn{2}{|l|}{ Jika ya sebutkan } \\
\hline 7. & \multicolumn{2}{|l|}{ Apakah anda pernah mengalami penyakit ginjal? } \\
\hline 8. & \multicolumn{2}{|l|}{ Apakah anda pernah mengalami penyakit kuning dalam kehamilan ini? } \\
\hline \multirow[t]{2}{*}{9.} & $\begin{array}{l}\text { Apakah sebelum atau pada kehamilan ini anda didiagnosis do kter dengan } \\
\text { sindrom sistemik lupus atau anti fosfolipid sindrom? }\end{array}$ & \\
\hline & Riwayat Penyakit Keluarga & \\
\hline \multirow[t]{2}{*}{10.} & Apakah di keluarga ada yang mengalami tekanan darah tinggi selama hamil? & \\
\hline & Jika ya, siapa? & \\
\hline \multirow[t]{2}{*}{11.} & Apakah di keluarga ada yang mengalami preeklamsia selama keha milan? & \\
\hline & Jika ya, siapa? & \\
\hline \multirow[t]{2}{*}{12.} & Apakah di keluarga ada yang mengalami penyakit diabetes (kencing manis)? & \\
\hline & Jika ya, siapa? & \\
\hline \multirow[t]{2}{*}{13.} & Apakah di keluarga ada yang mengalami penyakit diabetes (kencing manis)? & \\
\hline & Jika ya, siapa? & \\
\hline
\end{tabular}


KUESIONER II: FORM PEMERIKSAAN FISIK

No Responden

PEMERIKSAAN FISIK

\begin{tabular}{|c|c|c|c|c|c|}
\hline Tekanan darah & \multicolumn{2}{|c|}{....../... $\mathrm{mmHg}$} & Nadi .......x/m & Respirasi ...x/m & Suhu ........ ${ }^{\circ} \mathrm{C}$ \\
\hline \multicolumn{2}{|l|}{ Berat badan } & \multicolumn{2}{|c|}{.................. kg } & \multicolumn{2}{|c|}{ Tinggi Badan: ........................cm } \\
\hline \multicolumn{2}{|l|}{ BB sebelum hamil } & \multicolumn{4}{|c|}{................ kg } \\
\hline \multirow[t]{2}{*}{ Abdomen } & Hepar & \multicolumn{4}{|c|}{ Tidak teraba/ teraba ..... } \\
\hline & Lien & \multicolumn{4}{|c|}{ Tidak teraba/teraba ...... } \\
\hline Umur kehamilan & \multicolumn{5}{|c|}{.... mg (berdasarkan HPM atau USG pertama kehamilan) } \\
\hline TFU & \multicolumn{5}{|l|}{$\ldots . . \mathrm{Cm}$} \\
\hline Jumlah janin & \multicolumn{5}{|c|}{ Tunggal/kembar } \\
\hline
\end{tabular}

KUESIONER III: FORM LABORATORIUM

No Responden

KUESIONER III: FORM LABORATORIUM

HASIL PEMERIKSAAN PENUNJANG DETEKSI DINI KEHAMILAN RISIKO TINGGI

\begin{tabular}{|l|l|l|l|}
\hline Pemeriksaan darah & Hasil & Nilai Normal & Kesimpulan \\
\hline Hemoglobin & & $12-16 \mathrm{~g} / \mathrm{dL}$ & \\
\hline Pemeriksaan urin & Hasil & Nilai Normal & Kesimpulan \\
\hline Glukosa & & $2-30 \mathrm{mg} / \mathrm{dL}$ & \\
\hline Protein & & negatif & \\
\hline Leukosit & & negatif & \\
\hline
\end{tabular}

